\title{
MOLLUSCUM CONTAGIOSUM: SEROLOGY AND ELECTRON MICROSCOPY FINDINGS IN TWENTY ONE PATIENTS
}

M. E. F. FONSECA (1), R. D. MACHADo (2), M. I. M. LIBERTO (2) \& G. MARCOLINO (3)

\section{S U M M ARY}

Twenty one cases of molluscum contagiosum virus disease were collected for electron microscopical and serological tests. Molluscum virus was detected in the crust, inside the vacuoles formed in the keratinocytes cells. The patients developed specific antibodies to the virus detected by complement fixation test.

KEY-WORDS: Molluscum contagiosum virus; Serology; Electron microscopy.

\section{N T R O D U C T I O N}

Molluscum contagiosum virus infects individuals of all ages throughout the world, but it predominantly affects children. Infection may last from several months to several years. It causes bening skin lesions in man and several of them are not uncommon to be found. Although the lesions of molluscum contagiosum are very typical, confirmatory laboratory tests can be used, such as electron microscopic and histological examination as well as serological tests. Virus isolation is almost impossible. This virus morphologically resembles those of the pox group 1 .

Recently, since the Summer of 1985 , several cases of molluscum contagiosum were diagnosed in Rio de Janeiro and in some regions of the northeast of the country. The cases occurred frequently in children and adolescents.

Here, we describe the electron microscopy and serological findings of molluscum contagiosum, in twenty one cases studied.

\section{MATERIAL AND METHODS}

Patients - During 1985, patients with clinically typical molluscum contagiosum, were refered from General Practioners of Sergipe (northeastern State of Brazil) and Rio de Janeiro. The patients ranged from 5 months old up to 19 years old. Most of them were infants (71.4\%) and two young patients, were students of the State University of Rio de Janeiro (UERJ). Disseminated lesions were observed on the trunk, genitals, axilla, neck, face and last for over 6 months.

Specimens - The specimens for virus examination were collected by curettage and ob. served at electron microscopy, after resin embedding, carried out by means of standard methods. Papular extract and crusts, were also obtained and examined by negative staining, with $4 \%$ PTA for one minute and uranyl acetate for 30 seconds.

Cases studied - Twenty one cases wereused in this study (Table I). Blood specimens.

(1) Setor de Microscopia Eletrónica do Instituto de Microbiologia da UFRJ.

(2) Departamento de Virologia do Instituto de Microbiologia da UFRJ.

(3) Universidade Federal de Sergipe.

Address for correspondence:

Prof. Maria Evangelina Ferreira Fonseca

Centro de Ciências da Saúde - Bloco I.

Departamento de Virologia - Setor de Microscopia Eletrônica do Instituto de Microbiologia da UFRJ. Caixa Postal 68040.

Cidade Universitária. CEP 21944 Rio de Janeiro, RJ, Brasil. 
FONSECA, M. E. F.; MACHADO, R. D.; LIBERTO, M. I. M. \& MARCOLINO, G. - Molluscum contagiosum: serologJ and electron microscopy findings in twenty one patients. Rev. Inst. Med. trop. São Panlo, 29:86-89, 1987.

were collected from seventeen of them and specific antibodies against molluscum contagiosum virus were detected by complement fixation test ${ }^{3}$ using specific antigen obtained from the molluscum papules on the skin of patients which were curetted, weighed and ground in a tenbroeck, with the addition of enough sterile PBS solution, to make $10 \% \mathrm{w} / \mathrm{v}$ suspension ${ }^{4}$. The suspension was clarified and stored at $4 .^{\circ} \mathrm{C}$

T A B I $\mathbf{E}$ I

Patients data and specimens collected for mollusculum contagiosum diagnosis

\begin{tabular}{|c|c|c|c|c|}
\hline $\begin{array}{l}\text { N. of patients } \\
\text { studied }\end{array}$ & $\begin{array}{c}\text { Specimen } \\
\text { tested }\end{array}$ & $\begin{array}{l}\text { Type of } \\
\text { test }\end{array}$ & $\begin{array}{l}\text { Clinical } \\
\text { findings }\end{array}$ & Patients age \\
\hline 12 & paired sera & $\begin{array}{l}\text { complement fixation } \\
\text { test }\end{array}$ & $\begin{array}{l}\text { typical Molluscum } \\
\text { Contagiosum }\end{array}$ & $\begin{array}{l}\text { Aged between } 5 \text { months } \\
\text { old up to } 19 \text { years old }\end{array}$ \\
\hline 5 & convalcscent sera & $\begin{array}{l}\text { complement fixation } \\
\text { test }\end{array}$ & $\begin{array}{l}\text { typical Molluscum } \\
\text { Contagiosum }\end{array}$ & $\begin{array}{l}\text { Aged from } 4 \text { years old } \\
\text { up to } 13 \text { years old }\end{array}$ \\
\hline 4 & $\begin{array}{l}\text { papular extract } \\
\text { crust } \\
\text { Molluscum lesions }\end{array}$ & $\begin{array}{l}\text { electron microscopy } \\
\text { (negative staining } \\
\text { and thin sectioning) }\end{array}$ & $\begin{array}{l}\text { typical Molluscum } \\
\text { Contagiosum }\end{array}$ & $\begin{array}{l}\text { Aged } 2,3,8 \text { and } 17 \text { years } \\
\text { old respectively }\end{array}$ \\
\hline
\end{tabular}

Typical Molluscum Contagiosum: Papules and crust last for months on trunk, axilla, neck, face and genitals.

\section{RESULTS}

Paired sera were obtained from twelve patients and complement fixation antibodies were detected in six patients, in their first serum. All second sera samples, obtained from seventeen patients, revealed the presence of specific antibodies, varying in titres from $1 / 64$ up to $1 / 256$. There was serum conversion in the twelve paired sera obtained as seen in Table II.

T A B L E II

Results of complement fixation test to Molluscum Contagiosum

\begin{tabular}{|c|c|c|c|c|}
\hline Patients & Age & $\begin{array}{c}1 \text { st serum } \\
\text { titer } 1 /\end{array}$ & $\begin{array}{c}2 \text { nd serum } \\
\text { titer } 1 /\end{array}$ & $\begin{array}{c}\text { Interval between } \\
2 \text { nd sera and the } \\
1 \text { st sera }\end{array}$ \\
\hline 1 & 5 months & 4 & 64 & 15 days after \\
\hline 2 & 3 years & $\mathbf{0}$ & 256 & 15 days after \\
\hline 3 & 11 months & 8 & 128 & 15 days after \\
\hline 4 & 7 years & 0 & 64 & 20 days after \\
\hline 5 & 7 years & $\mathbf{0}$ & 256 & 25 days after \\
\hline 6 & 8 months & 16 & 128 & 16 days after \\
\hline 7 & 12 years & 32 & 256 & 13 days after \\
\hline 8 & 10 years & 0 & 64 & 21 days after \\
\hline 9 & 13 years & $\mathbf{0}$ & 256 & 12 days after \\
\hline 10 & 9 years & 16 & 128 & 12 days after \\
\hline 11 & 19 years & 32 & 512 & 12 days after \\
\hline 12 & 5 years & $\mathbf{0}$ & 256 & 22 days after \\
\hline 13 & 4 years & - & 256 & *5 weeks later \\
\hline 14 & 4 years & - & 512 & - 5 weeks later \\
\hline 15 & 6 years & - & 64 & *6 weeks later \\
\hline 16 & 13 years & 一 & 128 & *5 weeks later \\
\hline 17 & 11 years & - & 128 & -5 weeks later \\
\hline
\end{tabular}

- not collected.

- Weeks after the onset of the disease.

Molluscum contagiosum antigen obtained from lesions minced in PBS, pH 7.2 (MITCHELL 4).
Electron microscopic studies of papular extracts were negative. But when crusts were observed, it was easy to detect the virion particles. Their morphology were typical to that observed for poxvirus group (see figure 1). Most of the particles were in the $M$ form and their size was $200 \mathrm{~nm} \times 300 \mathrm{~nm}$.

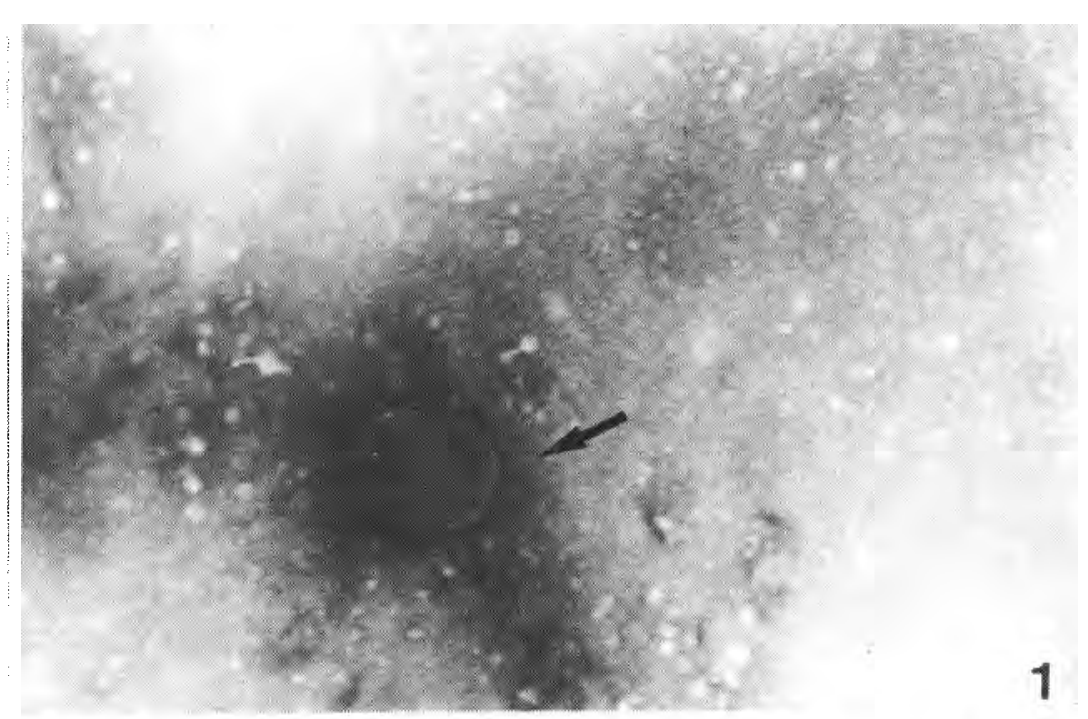

Fig. 1 - Negative staining of molluscum contagiosum crust. Viral particle (see arrow) is brick-shaped with $200 \times 300 \mathrm{~nm}$ size. Magnification: 90.000

Sections were rich in viruses enclosed in the cytoplasm of the keratinocyte cell, forming the "molluscum bodies" (figure 2). Mature virions collected in citoplasmic vacuoles, recognizable by their dumbell-shaped nucleoids and brick-shape capsules, were outlined by trabeculae containing immature viruses (figure 3 ). 
FONSECA, M. E. F.; MACHADO, R. D.; LIBERTO, M. I. M. \& MARCOLINO, G. - Molluscum contagiosum: serologg and electron microscopy findings in twenty one patients. Rev. Inst. Med. trop. São Paulo, 29:86-89, 1987.

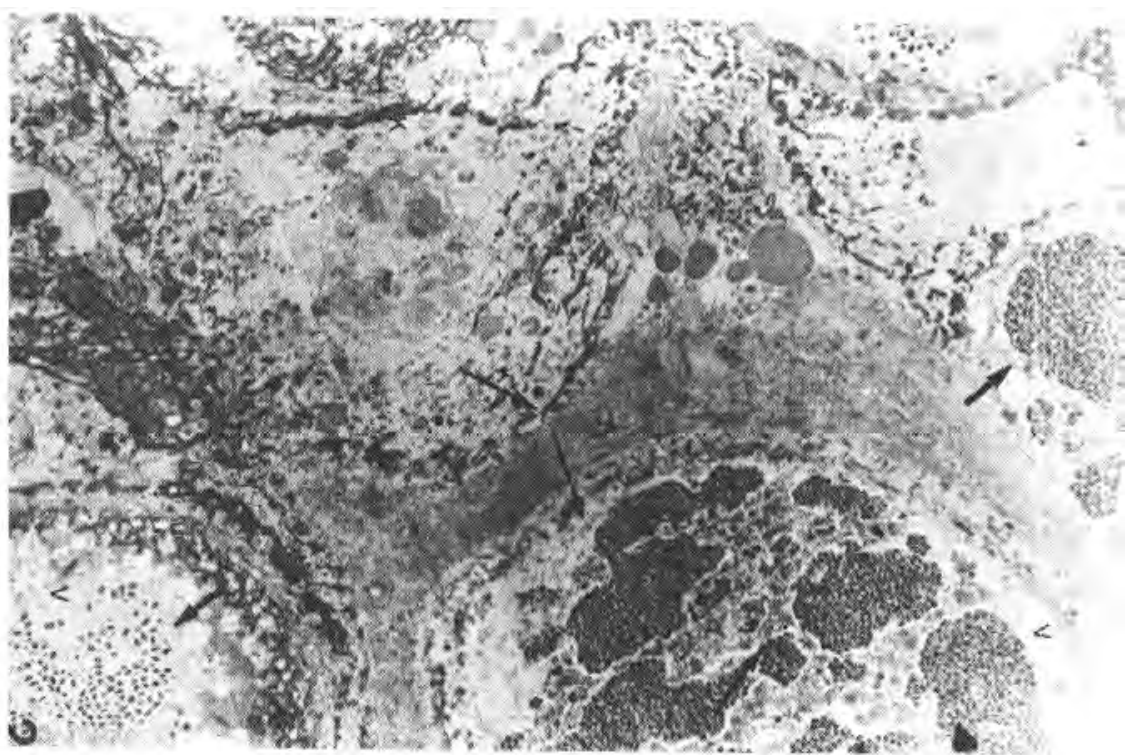

Fig. 2 - Thin section of epidermal cell collected by curettage. Keratinocytes infected with poxvirus (arrows). $\mathrm{K}=$ keratin; $\mathrm{V}=$ vacuoles. Magnification: 5.000

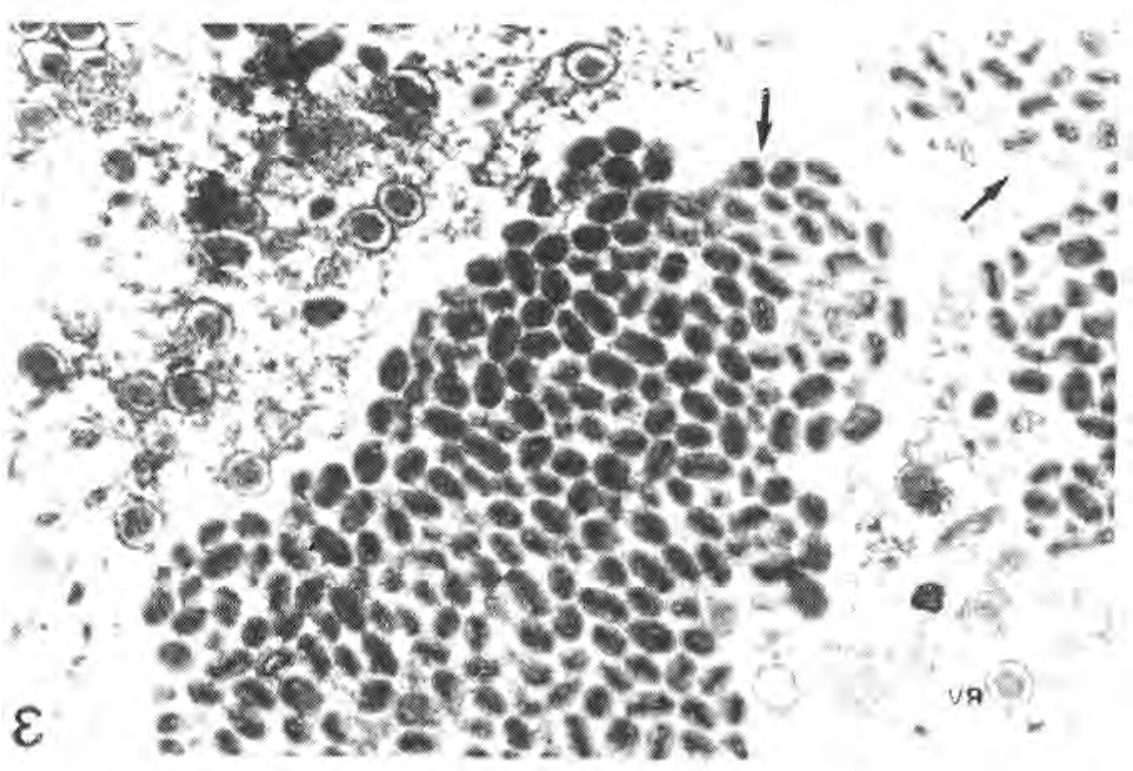

Fig. 3 - Higher magnification of the cells infected with molluscum contagiosum virus. Mature viruses have dumbell-shaped nucleoids (arrow) Round viruses are in an immature form (RV). Magnification: $\mathbf{3 8 . 0 0 0}$

\section{DISCUSSION}

The molluscum contagiosum virus, a member of the poxvirus group, is a large brick shape DNA-containing virus which replicates in the keratinocyte cytoplasm ${ }^{2}$. Our observations with the electron microscope confirmed that the virus replicates in a viroplasmic foci, accumulating in a vacuolated area, becoming the host cell filled with viruses. The core of the lesion consisted of degenerating epidermal cells with inclusion bodies and keratin, which is still produced by uninfected cells.
Because the molluscum contagiosum virus. is strictly limited to human skin, virus specific antibodies are demonstrable in only about $70 \%$ of patients ${ }^{6}$. But this survey revealed that $100 \%$ of the patients with molluscum contagiosum virus, even the babies, developed complement fixation antibodies in high titres. Serological conversion was also observed in twelve patients studied. Since variola immunization is no longer administrated, it is probable that the children on this survey, do not have specific antibodies to the vaccinia virus. Perhaps the lack of such immunity favoured the establishment of the molluscum virus, increasing its incidence in our people and facilitating the development of molluscum virus antibodies. As revealed by PIRIE \& col.5, molluscum contagiosum virus has been shown to be very similar to vaccinia virus in chemical composition and physical properties, but on the grounds of serology, Mitchell observed no cross-reactions between molluscum contagiosum virus and vaccinia, cowpox or fowl poxviruses, by complement fixation test.

\section{RESUMO}

\section{Molusco contagioso: sorologia e microscopia} eletrônica em vinte e um pacientes.

Vinte e um casos de molusco contagioso foram escolhidos para serem analisados por testes sorológicos e de microscopia eletrônica. O vírus do molusco foi detectado nas crostas e observados também nos vacúolos formados dentro dos queratinócitos.

Os pacientes desenvolveram anticorpos fixadores do complemento para o vírus.

\section{ACKNOWLEDGMENTS}

Work realized with grant awarded by CNPq. We are grateful to Venício Féo da Veiga and Paulo Roberto de Andrade Rios, for their technical help.

\section{REFERENCES}

1. FENNER, F. - Poxviruses. In: FIELDS, B. N.; KNIPE, D. M.; CHANOCK, R. M.; MELNICK, J. L.; ROIZMAN, B. \& SHOPE, R. - Virology. New York, Raven Press, 1985. p. $661-703$. 
FONSECA, M. E. F.; MACHADO, R. D.; LIBERTO, M. I. M. \& MARCOLINO, G. - Moliuscum contagiosum: serologY and electron microscopy findings in twenty one patients. Rev. Inst. Med. trop. Sâa Paulo, 29:86-89, 1987.

2. HASHIMOTO, K. \& NIIZUNA, K. - Skin pathology by light and electron microscopy. Tokyo, Igaku-Shoin, 1983. p. 155-173.

3. LENNETTE, E. H. \& SCHMIDT, N. J. - Diagnostic procedures for viral, rickettsial and chlamydial infections. Washington D.C., American Public Health Assoc., 1979. p. 35-42.

4. MTTCHELL, J. - Observation on the virus of molluscum contagiosum. Brit. exp. Path., 34: 44-49, 1953.
5. PIRIE, G. D.; BISHOP, P. M.; BURKE, D. C. \& POSTLETHWAITE, R. - Some properties of purified molluscum contagiosum virus. J. gen. Virol., 13: 311-320, 1971 .

6. SHIRODARIA, P. V. \& MATHEWS, R. S. - Observations on the antibody response in molluscum contagiosum. Brit. J. Derm., 96: 29-34, 1977.

Recebido para publicação em 27/6/86. 